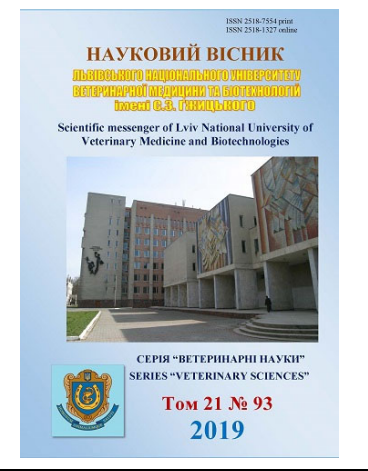

\author{
Науковий вісник Дьвівського національного університету \\ ветеринарної медицини та біотехнологій імені С.З. Гжицького. \\ Серія: Ветеринарні науки \\ Scientific Messenger of Lviv National University \\ of Veterinary Medicine and Biotechnologies. \\ Series: Veterinary sciences
}

UDC 636.22/28:612.

\title{
Haematological indicators in high-produced cows in dynamics of dry period
}

\author{
L.V. Koreyba \\ Dnipro State Agrarian and Economic University, Dnipro, Ukraine
}

Article info

Received 22.01.2019

Received in revised form 01.03 .2019

Accepted 02.03.2019

Dnipro State Agrarian and Economic University, Serhiya Yefremova Str., 25, Dnipro, 49000, Ukraine.

Tel.: +38-056-68-33-77

E-mail:lyudkorflk@gmail.com
Koreyba, L.V. (2019). Haematological indicators in high-produced cows in dynamics of dry period. Scientific Messenger of Lviv National University of Veterinary Medicine and Biotechnologies. Series: Veterinary sciences, 21(93), 37-40. doi: 10.32718/nvlvet9307

An analysis of literary sources on issues of a property of the blood and hemostasis suggests that this problem is a significant consideration given to human medicine. There is ongoing research on the properties of blood and systems of hemostasis in female animals at the time of feeding the fetus, their impact on the indices of reproductive function and viability of the offspring remains beyond the attention of researchers. The goal of the work was to study the dynamics of haematological parameters in cows of Holstein Black-and-White breed during the dry period. The research was carried out on the cows in the dynamics of the physiological course of the dry period (from the 8th to the 9th months of calving). Hematologic studies of blood samples taken from the cows in the course of the dry period were carried out according to generally accepted methods. The results of our research indicated that deep-calving cows show a decrease in the number of red blood cells, an increase in the number of leukocytes, an increase in the oxygen capacity of the blood and an increase in the colour index. The haemoglobin content and energy potential increased, the number of lymphocytes and neutrophils with segmental nucleus increased, and the number of neutrophils with a stick-shaped nucleus decreased as well. Consequent$l y$, the characteristics features of homeostasis of deep-calving cows are: reducing the number of erythrocytes and increasing the number of leukocytes, increasing the oxygen capacity of the blood and increasing the color index, hemoglobin content and energy potential; an increasing the number of lymphocytes, segmental neutrophils, as well as reducing neutrophils with a stick-shaped nucleus. Further work will have a focus on determining the haematological parameters of high-yielding cows in the post-partum period for studying the overall resistance of the body, as well as the prediction and correction of obstetric pathology.

Key words: blood, morphological indices, haematological research.

\section{Гематологічні показники у високопродуктивних корів в динаміці сухостійного періоду}

\author{
Л.В. Корейба
}

Дніпровський державний аграрно-економічний університет, м. Дніпро, Україна

\footnotetext{
Аналіз літературних джерел з питань властивостей крові та гемостазу свідчить, щзо даній проблемі значна увага приділяється у гуманній медицині. Що стосується досліджень властивостей крові та системи гемостазу у самок тварин під час виношування плоду, їхній вплив на показники репродуктивної функиії та життєздатність приплоду залитився поза увагою дослідників. Дослідження проводились на коровах в динаміці фізіологічного перебігу сухостійного періоду (з 8-го по 9-тий місяці тільності). Гематологічне дослідження зразків крові, відібраних від тільних корів впродовж сухостійного періоду, проводили за загальноприйнятими методиками. Встановлено, щзо в глибокотільних корів відмічається зниження чисельності еритрочитів до 7,12 \pm

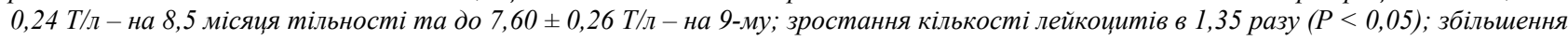

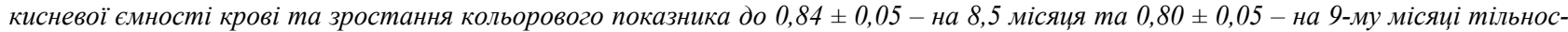
ті, вмісту гемоглобіну на $5 \%$ й енергетичного потенціалу; збільшення кількості лімфоцитів на 2,5\%, сегментоядерних нейтрофі-
} 
лів в 1,15 разу (P<0,05), зниження палочкоядерних нейтрофілів в 1,86 разу $(P<0,01)$. Отже, характерною рисою гомеостазу глибокотільних корів є: зниження чисельності еритроцитів та зростання кількості лейкоцитів, збільшення кисневої ємності крові та зростання кольорового показника, вмісту гемоглобіну й енергетичного потенціалу; збільшення кількості лімфоцитів, сегментоядерних нейтрофілів, а також зниження палочкоядерних нейтрофілів. Подальша робота буде зосереджена на визначенні гематологічних показників високопродуктивних корів в післяродовий період для вивчення загальної резистентності організму, а також прогнозування та корекції акушерської патологї.

Ключові слова: корови, сухостійний період, кров, морфологічні показники, гематологічне дослідження.

Вступ

Будь-який організм відповідно до генотипу за різних умов, у тому числі й екстремальних, володіє здатністю зберігати постійність гомеостазу. На гематологічні, біохімічні та інші показники суттєвий вплив має не тільки фізіологічний стан тварини (вік, вагітність, продуктивність), а й умови утримання, годівлі та експлуатації (Petrovskij, 1995; Safonov et al., 2008; Koreyba \& Duda, 2018; Bomko et al., 2018; Koreyba, 2018).

Виношування плоду супроводжується змінами реологічних властивостей крові самок, які забезпечують формування умов за для його фізіологічного росту та розвитку. Однак, фізіологічність системи гемостазу у значній ступені залежить від властивостей крові (Zamazii et al., 2015).

Згідно даних І.С. Кучерова (1991), вагітність корів істотно не впливає на показники червоної та білої крові. За даними інших авторів (Petrovskij, 1995; Safonov et al., 2008; Gerardo, 2009; Piccione et al., 2012), вона впливає на гематологічні показники. Авторами встановлено, що кров тільних корів більш насичена гемоглобіном, має вищий вміст еритроцитів i лейкоцитів, починаючи 3 другої половини тільності, особливо після запуску і безпосередньо перед отеленням.

Наголошується, що морфологічний склад крові вагітних тварин характеризується рухомою рівновагою: зі збільшенням термінів вагітності кількість еритроцитів та лейкоцитів дещо зростає й досягає максимальної величини під час родів. Про зростання кількості еритроцитів і гемоглобіну в крові корів у другій половині вагітності свідчать дані інших авторів (Kucherov, 1991).

Аналіз літературних джерел 3 питань властивостей крові та гемостазу свідчить, що даній проблемі значна увага приділяється у гуманній медицині. Що стосується досліджень властивостей крові та системи гемостазу у самок тварин під час виношування плоду, їхній вплив на показники репродуктивної функції та життєздатність приплоду залишився поза увагою дослідників.

Тому мета нашої роботи полягала у вивченні динаміки гематологічних показників у корів голштинської чорно-рябої породи в період сухостою.

\section{Матеріал і методи досліджень}

Дослідження проводились в Науково-виробничому об’єднанні агрофірми “Наукова” Дніпропетровського району Дніпропетровської області на коровах голштинської породи з молочною продуктивністю 5-6 тис. кг за лактацію в динаміці фізіологічного перебігу сухостійного періоду (з 8-го по 9-тий місяці тільносTi).

Комплекс для великої рогатої худоби у господарстві побудований для безприв язного "холодного" утримання корів з боксами для відпочинку місткістю на 2100 голів.

Для раціонального утримання корів їх розподіляють у групи за фізіологічним станом. Залежно від фізіологічного стану молочне стадо розподілено на чотири технологічні групи, які розміщені в цехах: сухостійних корів, отелення, роздою і осіменіння, виробництва молока. У кожному цеху тварини перебувають певний період, після чого їх переводять у наступний цех по замкненому колу.

Вагітні тварини перебували під постійним ветеринарним контролем. Контрольні та дослідні групи формувались за принципом груп-аналогів (за породою, віком, фізіологічним станом, масою, молочною продуктивністю); в дослідах 3 вивчення сезонних особливостей - за принципом груп-періодів.

Для кожної групи корів складався власний раціон 3 метою відповідності годівлі тварин науковообгрунтованих норм годівлі. Годівля тварин в господарстві базується на власній кормовій базі. Особливістю годівлі великої рогатої худоби в умовах господарства $є$ перехід на цілорічну годівлю тварин раціонами із застосуванням сінажу, силосу злаковобобових трав та кукурудзяного силосу, який готується в поліетиленових тубах за американською технологі$є ю$ “Ag-Bag”, силосних ямах та курганах.

Лабораторні дослідження крові відібраних від тільних корів упродовж сухостійного періоду проводили за загальноприйнятими методиками (Levchenko et al., 2002; Vlizlo et al., 2012).

\section{Результати та їх обговорення}

Отримані нами результати досліджень показані в таблиці 1. 3 таблиці видно, що характерною рисою для глибокотільних корів господарства було зниження чисельності еритроцитів (до 7,12 \pm 0,24 Т/л - на 8,5 місяця тільності та до 7,60 \pm 0,26 Т/л - на 9-му), що, можливо, пов'язано з умовами годівлі та утримання тварин на фоні стану вагітності. При цьому спостерігали збільшення кисневої ємності крові (вміст гемоглобіну зріс на 5\%).

Кольоровий показник крові теж зазнавав змін. Нами відмічено його зростання до $(0,84 \pm 0,05-$ на 8,5 місяця та 0,80 $\pm 0,05$ - на 9-му місяці тільності), що вказує про зростання енергетичного потенціалу у глибокотільних корів. Разом $з$ тим кількість лейкоцитів в середині сухостійного періоду зросла в 1,35 разу 
$(\mathrm{P}<0,05)$, залишаючись при цьому в межах фізіологічної норми. На нашу думку, це відбувається під впливом продуктів життєдіяльності плоду на імунну систему матері, що в своєю чергою веде до посилення захисних властивостей організму у зв'язку з вагітністю.

\section{Таблиця 1}

Гематологічні показники у корів в динаміці сухостійного періоду ( $\mathrm{M} \pm \mathrm{m})$
Великою і функціонально важливою групою лейкоцитів у крові $\epsilon$ нейтрофіли та лімфоцити, які $\epsilon$ основними імунокомпетентними клітинами (Kucherov, 1991; Khariv \& Hutyi, 2017).

\begin{tabular}{lrrr}
\hline \multicolumn{1}{c}{ Показники } & \multicolumn{3}{c}{ Термін тільності, міс. } \\
\cline { 2 - 4 } & $8(\mathrm{n}=8)$ & $8,5(\mathrm{n}=10)$ & $9(\mathrm{n}=12)$ \\
\hline Еритроцити, Т/л & $7,72 \pm 0,25$ & $7,12 \pm 0,24$ & $7,60 \pm 0,26$ \\
Гемоглобін, Г/л & $113,15 \pm 4,22$ & $119,74 \pm 5,53$ & $118,81 \pm 4,95$ \\
Кольоровий показник & $0,74 \pm 0,05$ & $0,84 \pm 0,05$ & $0,80 \pm 0,05$ \\
ШОЕ, мм/год & $0,99 \pm 0,08$ & $1,25 \pm 0,08^{*}$ & $1,38 \pm 0,11^{*}$ \\
Лейкоцити, Г/л & $7,51 \pm 0,39$ & $10,12 \pm 1,10^{*}$ & $9,61 \pm 0,98$ \\
\hline
\end{tabular}

Примітка: *P $<0,05, * * \mathrm{P}<0,01$ стосовно до 8-ого місяця тільності; $* \mathrm{P}<0,05, * * \mathrm{P}<0,01$ стосовно до 8,5-ого місяця тільності.

В лейкограмі крові зміни відбулися за рахунок збільшення кількості лімфоцитів на 2,5\%, сегментоядерних нейтрофілів - в 1,15 разу $(\mathrm{P}<0,05)$, при одночасному зниженні палочкоядерних - в 1,86 разу (P < 0,01). Тобто спостерігався перерозподіл нейтрофільних клітин вправо (рис. 1).
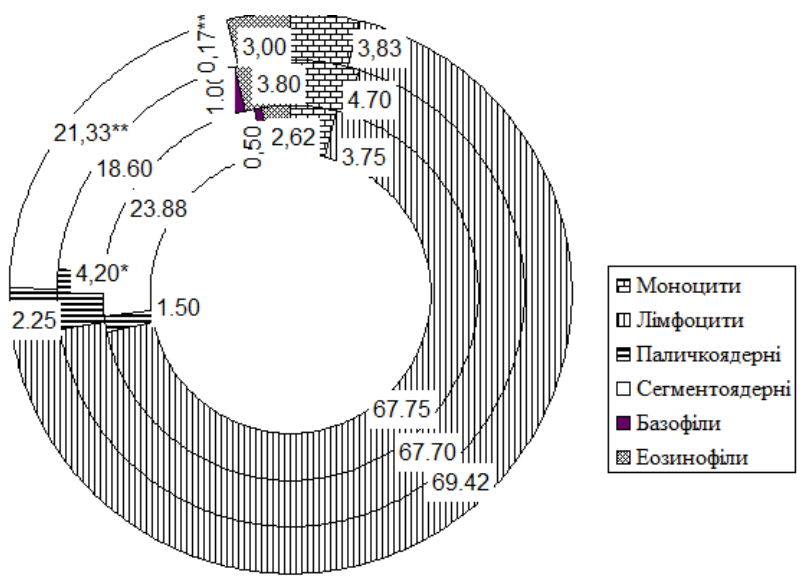

Рис. 1. Лейкоформула крові сухостійних корів на 8,8,5 та 9-ому місяці тільності

Примітка: *P $<0,05, * * \mathrm{P}<0,01$ стосовно до 8-ого місяця тільності; $* \mathrm{P}<0,05, * * \mathrm{P}<0,01$ стосовно до 8,5 -ого місяця тільності.

\section{Висновки}

Отже, характерною рисою гомеостазу глибокотільних корів $є$ : зниження чисельності еритроцитів та зростання кількості лейкоцитів, збільшення кисневої ємності крові та зростання кольорового показника, вмісту гемоглобіну й енергетичного потенціалу; збільшення кількості лімфоцитів, сегментоядерних нейтрофілів, а також зниження палочкоядерних нейтрофілів.

Перспективи подальших досліджень. Подальша робота буде зосереджена на визначенні гематологічних показників високопродуктивних корів в післяродовий період для вивчення загальної резистентності організму, а також прогнозування та корекції акушерської патології.

\section{Referenses}

Bomko, V., Kropyvka, Yu., Bomko, L., Chernyuk, S., Kropyvka, S., \& Gutyj, B. (2018). Effect of mixed ligand complexes of Zinc, Manganese, and Cobalt on the Manganese balance in high-yielding cows during first 100-days lactation. Ukrainian Journal of Ecology, 8(1), 420-425. doi: 10.15421/2018 230.

Gerardo, F. (2009). Reference limits for biochemical and hematological analytes of dairy cows one week before and one week after parturition. Can. Vet. J., 50(4), 383388. https://www.ncbi.nlm.nih.gov/pubmed/19436445.

Koreyba, L.V., \& Duda, Yu.V. (2018). Osoblyvosti bilkovoho obminu u vysokoproduktyvnykh koriv $\mathrm{v}$ period sukhostoiu. Veterynarna biotekhnolohiia. biuleten., K. Instytut veterynarnoi medytsyny NAAN, 33, 66-70. http://vetbiotech.kiev.ua/uk/arhiv/3333/393-koreyba-1-v (in Ukrainian).

Koreyba, L.V. (2018). Clinical and haematological indices of the cows for acute catarrhal-purulent endometritis. Scientific Messenger of Lviv National University of Veterinary Medicine and Biotechnologies, 20(92), 121124. doi: 10.32718/nvlvet9225.

Khariv, M.I. \& Hutyi, B.V. (2017). Dynamika fahotsytarnoi aktyvnosti neitrofiliv u shchuriv za umov oksydatsiinoho stresu ta dii liposomalnoho preparatu. Biolohiia tvaryn, 19(1), 119-124. doi:10.15407/animbiol19.01.119 (in Ukrainian).

Kucherov, I.S. (1991). Fiziolohiia liudyny i tvaryn. K. Vyshcha shkola (in Ukrainian).

Levchenko, V.I., Sokoliuk, V.M., \& Bezukh, V.M. (2002). Doslidzhennia krovi tvaryn ta klinichna interpretatsiia otrymanykh rezultativ. Metodychni rekomendatsii. Bila Tserkva (in Ukrainian).

Petrovskij, G.S. (1995). Gematologicheskie pokazateli u sel'skohozjajstvennyh i domashnih zhivotnyh. Kartina krovi pri nekotoryh fiziologicheskih sostojanijah i vozdejstvijah vneshnej sredy. Veterinarnaja 
gematologija. Pod red. G.A. Simonjana. M. Kolos, 102-121 (in Russian).

Piccione, G., Messina, V., Marafioti, S., Casella, S., Giannetto, C., \& De Fazio, F. (2012). Changes of some haematochemical parameters in dairy cows during late gestation, post partum, lactation and dry periods. Vet Med Zoot. 58(80), 59-64. https://vetzoo.1smuni.lt/data/vols/2012/58/pdf/piccione .pdf.

Safonov, V.A., Nezhdanov, A.G., Reckij, M.I., \& Shushlebin, V.I. (2008). Izmenenija biohimicheskih pokazatelej krovi u vysokoproduktivnyh korov vo vtoroj polovine beremennosti i v poslerodovoj period.
Vestnik Rossijskoj akademii sel'skohozjajstvennyh nauk, 3, 74-76 (in Russian).

Vlizlo, V.V., Fedoruk, R.S., \& Ratych, I.B. (2012). Laboratorni metody doslidzhen u biolohii, tvarynnytstvi ta veterynarnii medytsyni. dovidnyk za red. V.V. Vlizla. Lviv. SPOLOM (in Ukrainian).

Zamazii, A.A., Kambur, M.D., \& Lisovenko, V.M. (2015). Fiziolohichni vlastyvosti krovi tilnykh koriv. Visnyk Sumskoho natsionalnoho ahrarnoho universytetu. Seriia. Veterynarna medytsyna, 1, 42-45. http://nbuv.gov.ua/UJRN/Vsna_vet_2015_1_12 (in Ukrainian). 